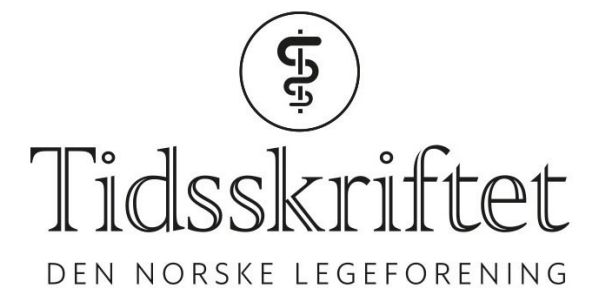

DEN NORSKE LEGEFORENING

\title{
Kroppen som mikrokosmos
}

PERSONLIGE OPPLEVELSER

\section{GEIR HELLEMO}

E-post: ghellemo@ulrik.uio.no

Geir Hellemo (f. 1950) er dr.theol. og tidligere rektor ved Det praktisk-teologiske seminar, Universitetet i Oslo.

Forfatter har fylt ut ICMJE-skjemaet og oppgir ingen interessekonflikter.

Når jeg som er teolog skriver om helse, har det en bestemt grunn. Jeg er blitt alvorlig syk. I møtene med ulike sider av helsevesenet har jeg gjort meg noen tanker - ettertanker som vedkommer flere enn meg.

Diagnosen min er motornevronsykdom som etter hvert forventes å utvikle seg til amyotrofisk lateral sklerose (ALS). I en liten brosjyre som jeg har fått tilsendt fra sykehuset, redegjør man for selve sykdomsbildet. Det sentrale innholdet knyttes til beskrivelsen av de biologiske prosessene i kroppen som har kommet i ulage: Motornevroner dør og gir ikke den nødvendige informasjonen som musklene trenger for å være virksomme. Dette er å forstå som en irreversibel prosess som er upåvirkelig i forhold til ytre stimuli. I klartekst betyr det at sykdommen er progredierende, og det finnes ingen form for behandling.

Det avgjørende spørsmålet for meg gjennom et sykdomsforløp som snart har vart i seks år, er knyttet til hvorledes man lever med en slik diagnose. Da jeg kom til firemånederskontrollen etter utredningen, var jeg frustrert over min livssituasjon. Jeg var i villrede. Jeg visste ikke hvorledes jeg skulle forholde meg til all usikkerheten som knyttet seg til min fremtid.

Møtet med nevrologene var forstemmende. Hovedinntrykket jeg sitter igjen med, er at ingenting nytter: Fysisk aktivitet gjør ingen forskjell. Selv når forverringen syntes å avta, fikk jeg forsikring om at den før eller siden ville innhente meg. Jeg fikk en klar fornemmelse av at jeg var en samling døde motornevroner som befant seg i et slags perspektivløst ingenmannsland: Foran meg lå en verden som etter hvert ville bli tømt for enhver form for aktivitet.

Dette gjorde meg selvsagt mismodig.

\section{Ingenting å gjøre}

Det beste jeg kan si i etterkant, er at det tydeliggjorde en faglig tilnærming med distinkte kjennetegn. Den fagligheten jeg møtte, isolerte sykdomsbildet fra resten av meg. Ikke slik å forstå at man bare interesserte seg for de rent biologiske prosessene. Man interesserte seg bare for de biologiske prosessene som var syke. Det betød at man forholdt seg til meg som bare syk. Men det var ikke det verste. Det verste var at denne tilnærmingen ble overført til alle de andre delene av helsevesenet som ble mobilisert i forhold til min sykdom. Alle 
tenkte det samme: Her er det ingenting å gjøre. Derfor gjør vi bare én ting: Vi gir den støtten som trengs på veien nedover. Og det som trengs på veien nedover, er først og fremst ulike former for hjelpemidler.

Etter hvert har jeg kommet til at selv om diagnostiseringen skulle være riktig, så er diagnostiseringsperspektivet ytterst problematisk: Det isolerer nemlig det syke fra alt annet på en måte som lammer langt ut over de lammelsene som allerede er der.

\section{Intensiv trening}

Jeg har imidlertid valgt meg en annen strategi i møtet med døde motornevroner enn den jeg ble forespeilet av helsevesenet. Umiddelbart etter at jeg var diagnostisert, sa en fysioterapeutvenn til meg: Be om å få to fysioterapitimer i uken, og start med hard og intensiv trening. Dette var et råd som ikke stemte godt overens med de retningslinjene som ALS-teamet la til grunn. Jeg har likevel fulgt vennerådet. Nå har jeg et treningsopplegg som er mer intensivt enn tidligere, i den forstand at jeg har gått over til daglige treningsøkter. Underveis har jeg lært at jeg må øve meg i å lytte bedre til kroppen enn jeg gjorde i startfasen. Men samtidig har jeg erfart at kroppen tilpasser seg og tåler stadig mer når den blir satt under press.

Det avgjørende i denne sammenhengen er imidlertid ikke i hvilken grad syk muskulatur lar seg trene eller ei, selv om også det er viktig. Det viktigste er at det er veldig bra for meg å trene. Det er bra å ha faste avtaler om regelmessig å oppsøke et fysisk stimulerende miljø. Men det er også bra å kjenne at jeg fortsatt har muskler som responderer når jeg bruker dem. Jeg liker å bruke dem, jeg kjenner endorfinene som utløses når jeg er i aktivitet, og jeg blir glad og tilfreds i etterkant.

Jeg har alltid likt å svømme. Etter at jeg ble syk har vi hatt lange vinteropphold på Costa Blanca. Det har hatt overraskende effekt. Ikke minst fordi ALS-teamet fortalte meg at behandlingsreiser ikke hadde noen effekt på den pasientgruppen jeg tilhører.

Min erfaring har vært en annen. Oppholdene i Spania har gjort vintrene tålelige på en ganske annen måte enn hjemme. Solen og varmen gjør godt for meg som for alle andre. Og så kommer jeg meg ut, timevis hver eneste dag, på en tid da det er umulig å oppholde seg ute i rullestol hjemme. Men aller viktigst er altså muligheten for daglige bassengbes $ø$ k. Min kropp gjør fremskritt når jeg er i basseng. Disse fremskrittene er ikke overveldende, men de er der. Kroppen blir mer bevegelig. Jeg sitter jo i rullestolen, sofakroken eller sengen, hele dagen. Da er det minimal bevegelse i underekstremitetene. Jeg beveger litt på tærne - ellers virker alt dødt. Derfor blir jeg forbløffet når jeg kommer i bassenget. Der kan jeg faktisk bevege meg, omtrent på vanlig vis. Jeg løfter bena og flytter dem fremover, jeg sykler, jeg står på dem når jeg støtter meg til bassengkanten, og skyver meg oppover ved muskelkraft i lår og sete.

\section{Det umulige er mulig}

Det kan ikke være vanskelig å skjønne at opplevelsen av alt dette er viktig. At jeg som ikke kan bevege meg, har funnet en arena hvor det umulige er mulig. Jeg gleder meg grenseløst over å få tilbake de mulighetene som ellers er tatt fra meg.

For ett år siden fikk jeg en telefon. En bekjent hadde fortalt om meg til en norsk-thailandsk massør, som syntes mitt tilfelle var interessant. Hun spurte om hun kunne få treffe meg. I etterkant har jeg fått massasje to ganger i uken. Massøren har et blikk for kropp som sammenhengende organisme som jeg aldri har sett maken til. Og det gir resultater. Tilstivnede muskler er blitt myke igjen, og blodsirkulasjonen i bena er blitt vesentlig forbedret. Hevelsene i føttene har forsvunnet. Muskulaturen er også blitt fyldigere, slik at jeg ikke sitter på knokler lenger. Bevegeligheten er også blitt noe bedre. Dette omhyggelige arbeidet med mitt syke legeme bæres av en fundamental omsorg for hele meg. Det må ikke forveksles med behagelig omgang med min syke kropp. Massasjen er tidvis særdeles smertefull. Likevel dreier det seg om en form for pleie av det som er ødelagt, som gir meg 
både livslyst og livsmot. Den bidrar til at jeg blir mindre fremmedgjort i forhold til alt i meg som er sykt. Jeg vedstår meg lettere hele meg gjennom den massasjen jeg får del i.

\section{Mestringsstrategier}

Det er en selvfølge at min sykdom virker inn på sinnet. Jeg trenger ikke å prøve å beskrive hvorledes det er å leve med de fremtidsutsiktene diagnosen gir meg. Men det som har stått klart fra første dag, har vært at jeg må ikke tenke for mye på det. Det er lettere sagt enn gjort. Når det først rakner, da må jeg bare vente. Vente på at mestringsstrategiene skal trå i kraft igjen. Jeg har i så måte vært heldig, fordi jeg har en faglig virksomhet å ty til. Det gir energi å være oppslukt av noe annet enn seg selv.

Så kunne jeg ha ramset opp alt i hverdagen som gjør godt. Men det sammenfattes på et vis i to grunnerfaringer. De kan begge knyttes til bestemte hendelser som har funnet sted. Den ene dreier seg om et dødsfall. En nær kollega døde under vårt forrige opphold i Spania. I dagene omkring selve dødsfallet og begravelsen tenkte jeg mye på det livet vi hadde delt. En av dagene satt jeg og hørte på stillferdig, seriøs musikk som passet godt for anledningen. Jeg var fattet, men trist. Så skjedde noe underlig. Da jeg hadde lagt hodetelefonene fra meg og gjort meg i stand til å gå ut, opplevde jeg noe helt nytt: Jeg åpnet utgangsdøren, og akkurat i det øyeblikket slo verden der ute imot meg med en kraft jeg aldri tidligere hadde kjent. Det var som om alt det som foldet seg ut foran mine øyne, absolutt alt, pustet, åndet, beveget seg, levde mer intenst enn før. Og så tenkte jeg: Dette er jeg en del av, og dette vil jeg være en del av. Det betyr: Jeg er ikke bare døde motornevroner, jeg er uendelig mye mer som fortsatt lever.

Det var det ene. Det andre knytter seg til de fremskrittene som faktisk finner sted oppi alle mine hverdager. De er små, og de endrer mine bevegelsesmuligheter i beskjeden grad. Men de er der. Og de bekrefter at det er møyen verd å være aktiv. Jeg tror det viktigste ved disse erfaringene er at de fører meg over fra et lukket til et åpnere univers. Dette har ingenting med falske forhåpninger å gjøre. Men det er blitt viktig å minne meg selv om at ingen vet hvordan min fremtid kommer til å se ut.

\section{Faglig diskurs}

Etter hvert har jeg oppfattet at mine erfaringer også hører hjemme innenfor en faglig diskurs. Jeg mangler forutsetninger for å være aktør i den debatten som finner sted. Men det er stimulerende å se sine egne erfaringer i lys av en faglig diskusjon som faktisk vedkommer meg på en direkte måte.

I Antonio Damasios bok Descartes' Error fra 1994 er det kroppen som utgjør grunnreferansen for forståelsen av mennesket. Denne kroppen samhandler som en helhet med miljøet, og de fysiologiske operasjonene som vi kaller sinnet, stammer fra denne strukturelle og funksjonelle helheten, ikke bare fra hjernen, sier Damasio (1). Dette høres umiddelbart helt selvfølgelig ut. Men slik er det ikke. Damasio påpeker at hjernens mest verdifulle produkt, sinnet, ikke har spilt noen hovedrolle innenfor studiet av hjernesykdommer, nemlig nevrologien.

Mine små faglige dykk har vært viktige for min egen del. De understøtter vissheten om at det er mye uutforsket i samspillet mellom omgivelsene, hjernens virksomhet og resten av kroppen som også kan vedkomme mitt sykdomsbilde. Nå tenker jeg at de syke nervecellene ikke bare er syke. De inngår i en dialog med hele kroppen og de livsbetingelsene jeg er underlagt. Og selv om denne dialogen ikke fører til at jeg blir frisk, så opprettholdes like fullt en form for dialog i meg mellom nervecellene mine, både de friske og de som er svekket, og annen virksomhet i kroppen, både i hjernen og i musklene. Alle disse nervecellene står i direkte kontakt med så vel sinnet som omgivelsene.

Dette er et annet perspektiv enn det jeg har møtt i helsevesenet, der de døde motornevronene fikk all oppmerksomhet. 
Nå er ikke mitt liv blitt dødt og tomt. På mange måter kan jeg si at jeg har levd rikere og dypere i disse siste årene enn noen gang tidligere. Det innebærer selvsagt ikke at jeg er glad for min skjebne. Langt derifra. Men langt, langt der inne ligger et ørlite håp om at skjebnen en dag kan bli vendt, ta en annen retning enn det spådommene tilsier. Enn så lenge bakser jeg meg videre og kjemper med utfordringer som hele tiden dukker opp i nye skikkelser. Men alt dette balet skaper til sammen en tilværelse som det er mulig å befinne seg i. Det er noe ganske annet enn å sitte å vente på at jeg skal bli innhentet av noe som ligger foran meg, og som bare er utålelig.

\section{LITTERATUR:}

1. Damasio AR. Descartes' Error. Emotion, Reason, and the Human Brain. New York: Avon Books, 1994: xvif.

Publisert: 21. august 2017. Tidsskr Nor Legeforen. DOI: 10.4045/tidsskr.17.0253 Mottatt 16.3.2017, godkjent 18.5.2017.

(C) Tidsskrift for Den norske legeforening 2020. Lastet ned fra tidsskriftet.no 